\title{
TOWARDS OPEN ACCESS TO UK RESEARCH
}

\author{
Frederick J. Friend, Honorary Director Scholarly Communication UCL
}

Progress towards open access to UK research reports is slow but steady. The growth in open access has been remarkable when the past ten years are set in the historical timescale of over 500 years of availability of print publications and over 300 years of scientific journal publishing. And yet so many more results from UK taxpayer-funded research could already have been made freely available if the UK Government had the vision to see the opportunities in new forms of scholarly communication. The story of open access in the UK is one of initiatives by organisations and individuals to develop the opportunities provided by new technologies, while the benefits from those initiatives have not been realized by a hesitant Government influenced by lobbying from vested interests.

\section{Academic origins}

The UK interest in open access to academic publications has roots in both the academic and the library communities. Although the origins of open access are perceived to be in the concerns of librarians about journal price rises, members of the academic community were the first to make preprints of research articles freely available on the internet through the use of open web-sites. "Self-archiving", as the practice came to be known, began on a large scale with the deposit of preprints by physics scholars in the arXiv database ${ }^{1}$. Professor Stevan Harnad of Southampton University had the vision to see how self-archiving could be extended to all research reports, stimulating an e-mail discussion on his "subversive proposal" in the summer of $2004^{2}$. The vision at that time was of fast electronic publication of preprints for which there was no market, leaving publishers to continue to publish the peer-reviewed version of an article. Publishers quickly realized, however, that their own future lay in electronic publication and - rightly or wrongly they perceive access to any version of a journal article to be part of the market from which they derive their profits. Publishers' concerns have increased as search engines have enabled easy access to the growing content in open repositories. Although Stevan Harnad sees "self-archiving" as no threat to conventional journal publication, it was inevitable that the "subversive proposal" became a business issue as well as a technical issue.

\section{The concerns of librarians}

Independently from Stevan Harnad's work, some members of the UK library community in the 1990s were thinking that change was necessary in the way in which scientific and

\footnotetext{
${ }^{1}$ This database currently provides open access to over 350,000 e-prints at www.arxiv.org .

${ }^{2}$ Harnad, Stevan (1995) A Subversive Proposal. In: Ann Okerson \& James O'Donnell (Eds.) Scholarly Journals at the Crossroads; A Subversive Proposal for Electronic Publishing. Washington, DC., Association of Research Libraries, June 1995. http://www.arl.org/scomm/subversive/toc.html
} 
medical journals are made available to those who needed access to the research those journals contained. To librarians whose professional motivation was to provide access for the maximum number of readers to the maximum quantity of relevant content, it was frustrating to have to exclude readers outside publishers' licensing definitions and to have to cancel titles known to be of value to readers. Although librarians regularly asked for higher budgets, price rises continually outstripped the extra money made available, as when the UK Government made an extra $£ 10$ million available to academic libraries ${ }^{3}$ in 1987 and the inflationary effect led to a further rise in journal prices.

During the 1990s UK librarians were looking across the Atlantic for new publishing models. The Mellon-funded project JSTOR ${ }^{4}$ attracted a great deal of interest as an innovative collaboration, although the value of JSTOR was perceived to be in saving costs on the storage of low-use volumes rather than on the purchase of current journals. Of more general application was the formation of SPARC, the Scholarly Publishing and Academic Resources Coalition ${ }^{5}$, which held out the promise of competition for highpriced journals from new low-priced journals and of alliances to support those new journals. One feature noticeable in visiting the US at that time was the involvement of senior members of the academic community with scholarly communication issues, an involvement then - but not now - missing in the UK. The Tempe meeting in March $2000^{6}$ illustrated academic involvement, with the participation of a number of Presidents, Provosts and Deans of US universities as well as leading members of learned societies. Both JSTOR and SPARC had in common collaboration between various stakeholders as their way of working, and the value of this approach was not lost upon the UK library community following US developments.

\section{The JISC and scholarly communication developments}

The Joint Information Systems Committee, JISC, "supports further and higher education by providing strategic guidance, advice and opportunities to use information and communications technology"7. It was natural therefore that the JISC should have been monitoring new initiatives like SPARC and the Budapest Open Access Initiative ${ }^{8}$, and picked up feelings in the UK academic and library communities about the need for change in scholarly publishing. During the 1990s the JISC had funded the eLib Programme, having a major impact upon the development of electronic services to library

\footnotetext{
${ }^{3}$ The Standing Conference of National and University Libraries Annual Report 1987, SCONUL, 1988, pages 29-30 \& pp 7-8, ISSN 0263-6816

${ }^{4}$ The JSTOR story is told at http://www.jstor.org/about/background.html .

${ }^{5}$ The SPARC web-site is www.arl.org/sparc . A description of the importance of the SPARC Initiative in the context of changes in scholarly communication was published in 1998: Friend, Frederick J.

"Alternatives to Commercial Publishing for Scholarly Communication." Serials 11, no. 2 (July 1998): 163.

${ }^{6}$ http://www.arl.org/scomm/tempe.html

${ }^{7}$ From the JISC web-site www.jisc.ac.uk

${ }^{8}$ Several UK invitees joined the meeting arranged by the Soros Foundation in December 2001 which led to the Budapest Open Access Initiative www.soros.org/openaccess .
} 
users ${ }^{9}$. This Programme also prepared the way for later open access work, for example through the funding of the EPrints software ${ }^{10}$ developed at the School of Electronics and Computer Science at Southampton University. As the technical developments proceeded the need for change in the structure of scholarly communication came to be realized.

Accordingly in 2001 the JISC set up a Scholarly Communications Group to advise on actions the JISC might take. Much of the work of the Group has been in fact-finding and investigation of key issues through commissioned reports ${ }^{11}$. In 2002 the JISC embarked upon a major new Programme entitled "Focus on Access to Institutional Resources", FAIR $^{12}$. This Programme was designed to improve access to all types of content produced within UK universities and colleges by encouraging the development of institutional repositories. Whereas "self-archiving" advocates approached open access from an author's perspective, the FAIR Programme approached open access from the direction of institutional needs, but the two approaches coincided in meeting the needs of both authors and institutions. Out of the FAIR Programme came several services of value to UK universities and to academic institutions world-wide. For example, the RoMEO database ${ }^{13}$ has been invaluable in listing publishers' policies on repository content and the experience of the SHERPA consortium ${ }^{14}$ has helped other universities in setting up open repositories.

The success of the FAIR Programme has led to the funding of a new Digital Repositories Programme ${ }^{15}$ to run from 2005 to 2008 . Increasingly projects under this Programme link technical developments to cultural issues, as with the Institutional Repositories and Research Assessment project ${ }^{16}$ which is developing technical solutions to the integration of repository content into the national Research Assessment Exercise. Meanwhile the JISC has not neglected the second route to open access, the publication of open access journals or the conversion of existing journals from subscription to open access, and in particular JISC has wished to support publishers willing to undertake trials of the open access model. The JISC Journals Working Group has been as interested as the Scholarly Communication Group in the development of new models and from 2003 to 2006 has provided funds to a variety of publishers in support of a transition from a subscription to an open access model. This funding has encouraged UK authors to submit papers to peerreviewed open access journals. Alongside these initiatives the JISC has funded advocacy

\footnotetext{
9 For an overview of the eLib Programme see Rusbridge, C. "Towards the hybrid library" D-Lib Magazine July-August 1998 http://www.dlib.org/dlib/july98/rusbridge/07rusbridge.html

10 The Eprints site is http://www.eprints.org/

11 The reports commissioned by the JISC Scholarly Communication Group can be found at http://www.jisc.ac.uk/index.cfm?name=jcie scg .

${ }_{12}$ The FAIR Programme is described at http://www.jisc.ac.uk/index.cfm?name=programme fair .

${ }^{13}$ Now managed as part of the SHERPA Project http://www.sherpa.ac.uk/romeo.php .

14 Twenty-one institutions and organizations are now part of the SHERPA service. See http://www.sherpa.ac.uk/about.html .

${ }^{15}$ The Digital Repositories Programme is described at http://www.jisc.ac.uk/index.cfm?name=programme digital repositories

${ }^{16}$ The IRRA project web-site is at http://irra.eprints.org/.
} 
work to explain to authors, to institutions and to publishers the benefits to be gained from new ways of disseminating academic content.

\section{The role of research funding agencies}

The Wellcome Trust was the first major UK funding agency to commit to open access. Its reasons for making this commitment are made very clear in a "position statement" on its web-site ${ }^{17}$ : "The Wellcome Trust has a fundamental interest in ensuring that the availability and accessibility of this material [i.e. journal articles resulting from Trustfunded research] is not adversely affected by the copyright, marketing and distribution strategies used by publishers." Before making this commitment the Trust had commissioned two studies into scholarly publishing, ensuring that its policy is built upon a factual foundation. Most of the UK Research Councils are also supportive of open access, but - unlike the Wellcome Trust - they have to take into account the views of the UK Government in determining their policies. A further complication has been the Research Councils' wish to agree policies in common, which can lead to a "lowest common denominator" result. Yet more pressure was exerted upon Research Councils UK through lobbying by publishers against RCUK's wish to support open access. With all these factors to consider, RCUK took over one year to finalise its policy, and the changes between the published draft and final versions were clear. Even so the RCUK "Position Statement on Access to Research Outputs"18 marks a significant step forward in the progress towards open access to the results of UK publicly-funded research.

\section{Parliamentary Enquiry and Government inaction}

The announcement of an Enquiry into Scientific Publishing by the UK Parliament's Science and Technology Committee came out of the academic experience of several Members of the Committee and also out of the realization that scientific publishing was not keeping pace with technological change. Ian Gibson MP expressed this dual inspiration in a Westminster Hall Debate on 15 December 2005: "Some members of the Committee who had experience of the publishing of academic journals knew how the problems had grown over the years and how, as in most things scientific and technological, the science and technology had moved on faster than regulation and faster than the communication of some of the discoveries that had been made."19 The Committee's Enquiry was thorough and resulted in a Report entitled "Scientific Publications: Free for All?"20 The Report gave strong support to the "self-archiving" route to open access in institutional repositories, but also recommended further development of open access journals. Unfortunately the UK Government failed to appreciate the benefits to the UK from the Committee's recommendations and issued a

\footnotetext{
${ }^{17}$ The Wellcome Trust position statement in support of open access is at http://www.wellcome.ac.uk/doc wtd002766.html .

${ }^{18}$ The RCUK "Position Statement on Access to Research Outputs" is at http://www.rcuk.ac.uk/access/index.asp .

${ }^{19} \mathrm{http}: / /$ www.publications.parliament.uk/pa/cm200506/cmhansrd/cm051215/hallindx/51215-x.htm

${ }^{20}$ HC399-I available electronically at http://www.publications.parliament.uk/pa/cm200304/cmselect/cmsctech/399/399.pdf
} 
Response $^{21}$, claiming to aim for a "level-playing field" for conventional and for new forms of scientific publishing but in fact doing nothing to facilitate the creation of that "level playing-field". Intense lobbying by vested interests was a major influence upon the Government's Response.

\section{The reaction of $U K$ publishers to open access developments}

The failure of many publishers to realize the opportunities for their businesses in open access developments is disappointing. When the RoMEO database $\mathrm{e}^{22}$ of publisher copyright policies was first established, most publishers willingly adopted "green" status, allowing authors to deposit copies of journal articles in repositories. During 2004 publishers began to express concern that large-scale take-up of the permission they had given could result in the cancellation of subscriptions by libraries, despite the fact that no evidence exists of cancellations on the basis of repository content. While publishers were unwilling to lose their "green" status, time embargoes on the deposit by authors began to be introduced and publishers hardened their attitude towards policy statements by funding agencies encouraging repository deposit. There may be business opportunities for publishers in new markets for journal content, in the same way as the popular music industry has adapted to the internet age, but even if publisher concerns about losses due to use of repository content prove to be justified, in delaying policy statements by funding agencies publishers have also delayed access to the research grants that can fund open access publication charges. The downward trend in library subscriptions has been clear for several years. Funding publication as part of the research process on an open access model will relate publication costs closely to research budgets, a relationship not achieved under the library subscription model. Open access publishers such as BioMedCentral and the Public Library of Science have committed fully to this model, and increasingly traditional publishers such as Oxford University Press have been willing to embark upon small-scale trials. However, the negative attitude towards open access fed into Government policy by the publishing industry has not as yet enabled the UK to seize the opportunities in the new information environment.

\section{Can the UK seize the opportunities provided by open access?}

The growth in interest in open access within the UK has as much to do with opportunities as it has to do with problems in the current scholarly communication model. The opportunities provided by the internet age are more fundamental than digitization of print and cannot be met as fully through the subscription and licensing model as through an open access model. This is evident in relation to the interaction between text and data. Research data is used in the preparation of a journal article, but a conventional journal cannot easily enable the reader to pass seamlessly from freely-accessible data to subscription-based text and vice-versa. In a speech in April 2002 Prime Minister Tony Blair recognized the importance of the development of the e-science Grid: "It's significant that the UK is the first country to develop a national e-science Grid, which

\footnotetext{
${ }^{21}$ Published in http://www.publications.parliament.uk/pa/cm200304/cmselect/cmsctech/1200/1200.pdf

${ }^{22}$ Now managed as part of the SHERPA Project http://www.sherpa.ac.uk/romeo.php .
} 
intends to make access to computing power, scientific data repositories and experimental facilities as easy as the Web makes access to information., ${ }^{, 23}$ The value of an open access business model to enable the benefits of these technological developments to be fullyrealized has not been appreciated by the Government.

Open access to research reports also benefits the research community in opening up possibilities of new collaborations between research groups who may not have had access to reports only available on subscription. The evidence is growing that open access leads to higher citations, improving the visibility of a nation's research. Changes in the way research is communicated can therefore provide the UK taxpayer with greater value for money from public investment in research. In this environment commercial and learned society publishers have an important role if they are prepared to change as radically as the research community they serve. The long history of research publication is a tradition of which the UK can be proud, and it is to be hoped that publisher and Government hesitation will not delay further the realization of the benefits from open access to UK research.

The views expressed in this chapter are those of the author and not necessarily those of any organization or institution for which the author works.

\footnotetext{
${ }^{23}$ The full text of the speech is available at http://www.pm.gov.uk/output/Page1715.asp .
} 